\title{
DIGLOSIA
}

Volume 2, Nomor 1 (Februari 2019)

p-ISSN 2615-725X (Print)

Halaman 59-72

e-ISSN 2615-8655 (Online)

\section{PENGEMBANGAN PEMBELAJARAN MENULIS TEKS CERAMAH DENGAN MODEL PROBLEM BASED LEARNING DIPADUKAN MEDIA GAMBAR PADA SISWA KELAS XI SMA}

\author{
Lia Kumala Sari ${ }^{1, *}$, Mohammad Siddik ${ }^{2}$, dan Widyatmike Gede Mulawarman ${ }^{3}$ \\ ${ }^{1}$ Magister Pendidikan Bahasa dan Sastra Indonesia, FKIP, Universitas Mulawarman \\ ${ }^{2,3}$ Fakultas Keguruan dan Ilmu Pendidikan, Universitas Mulawarman \\ 1,* Pos-el korespondensi: kumala1209@yahoo.com \\ ${ }^{2}$ Pos-el: hmsiddik@yahoo.com \\ ${ }_{3}^{3}$ Pos-el: widyatmikegedemulawarman@yahoo.co.id
}

\begin{abstract}
Writing entitled Development of Text Writing Lesson Lecture with Problem Based Learning Model Combined Image Media for Students Class XI on High School aims to examine the development of learning text writing lecture with Problem Based Learning (PBL) learning model with the belp of picture media in grade XI high school students. The scope of this development is limited only to planning, materials and evaluation in the learning process. The method used in this research is Research and Development ( $R \& D)$, using development research design with ADDIE model, ie Analysis (stage), Design (Design) stage, Development stage, Implementation stage and Evaluation stage (evaluation). Source of data that became the object in this research is the students of class XI in SMA Negeri 8 PPU. The results of development are obtained based on two aspects: feasibility, practicality and effectiveness. So that data obtained the feasibility of $71 \%$, practicality is $84 \%, 83 \%$ effectiveness. Overall the quality of teaching materials that are the product of this development is categorized as appropriate for the use of odd semester class XI students. The benefits of this development for Indonesian language teachers are expected to help as an alternative choice of text lecture lessons. For students, this development model can make students more creative, innovative, more productive. For the author itself is expected to be a means to deepen science. In addition, it is hoped that the results of development will be useful for the school as a useful source of information for the development of Indonesian language learning model.
\end{abstract}

Keywords: learning model, text writing lecture, high school

\begin{abstract}
ABSTRAK
Penelitian ini bertujuan untuk meneliti pengembangan pembelajaran menulis teks ceramah dengan model pembelajaran Problem Based Learning (PBL) dengan bantuan media gambar pada siswa kelas XI SMA. Ruang lingkup pengembangan ini dibatasi hanya pada perencanaan, materi dan evaluasi dalam proses pembelajaran. Metode yang digunakan penelitian ini adalah Research and Development (R\&D), dengan menggunakan desain penelitian pengembangan dengan model ADDIE, yakni tahap Analysis (analisis), tahap Design (desain), tahap Development (pengembangan), tahap Implementation (implementasi) dan tahap Evaluation (evaluasi). Sumber data yang menjadi objek dalam penelitian ini adalah siswa kelas XI di SMA Negeri 8 PPU. Hasil pengembangan diperoleh berdasarkan dua aspek, yaitu kelayakan, kepraktisan dan
\end{abstract}


keefektifan. Sehingga diperoleh data hasil kelayakan, yaitu 71\%, kepraktisan, yaitu $84 \%$, keefektifan, yaitu 83\%. Secara keseluruhan kualitas bahan ajar yang merupakan produk dari pengembangan ini dikategorikan layak untuk digunakan siswa kelas XI semester ganjil. Manfaat pengembangan ini bagi guru mata pelajaran bahasa Indonesia diharapkan dapat membantu sebagai salah satu alternatif pilihan pembelajaran teks ceramah. Bagi siswa, model hasil pengembangan ini dapat membuat siswa menjadi lebih kreatif, inovatif, lebih produktif. Bagi penulis sendiri diharapkan menjadi sarana untuk memperdalam ilmu pengetahuan. Selain itu, diharapkan hasil pengembangan nantinya bisa bermanfaat bagi sekolah sebagai sumber informasi yang bermanfaat bagi pengembangan model pembelajaran bahasa Indonesia.

Kata kunci: model pembelajaran, menulis teks ceramah, sekolah menengah atas

\section{A. PENDAHULUAN}

Kurikulum pendidikan di Indonesia dikembangkan berdasarkan budaya masyarakat dan karakteristik siswa. Paradigma baru ini memberikan otonomi luas pada tiap satuan pendidikan dan pelibatan masyarakat dalam rangka mengefektifkan proses belajar mengajar di sekolah. Dalam kurikulum 2013, guru dituntut untuk mampu mengubah sumber pembelajaran (learning resource) menjadi bahan ajar (teaching material). Selain itu, guru juga dituntut untuk mengembangkan model dan media pembelajaran sehingga mengurangi kejenuhan siswa saat belajar.

Jika hal ini terjadi di setiap proses belajar mengajar di berbagai lembaga pendidikan maka tujuan pembelajaran akan tercapai, yakni pemahaman optimal, penguasaan, aplikasi yang akurat sehingga tatanan kognitif, afektif dan psikomotorik akan stabil sebagaimana yang diharapkan tenaga edukatif pada umumnya. Ketiga ranah tersebut (kognitif, afektif, dan psikomotorik) merupakan faktor determinan untuk menentukan sukses tidaknya prestasi belajar siswa dalam sebuah pembelajaran yang mengacu pada sistem pembelajaran kurikulum 2013.

Jadi, peningkatan prestasi belajar siswa dapat diukur dengan perubahan hasil belajar siswa menjadi lebih baik dari proses pembelajaran sebelumnya. Sehingga peneliti mencoba untuk melakukan penelitian yang lebih mendalam dalam proses pembelajaran di kelas dengan mengangkat judul "Pengembangan Model Pembelajaran Menulis Teks Ceramah dengan Model Problem Based Learning Dipadukan Media Gambar pada Siswa Kelas XISMA”.

\section{B. LANDASAN TEORI}

1. Konsep Pengembangan Model Pembelajaran

Ada beberapa istilah tentang penelitian dan pengembangan, Brog \& Gall (dalam Sugiyono, 2006:28) menggunakan nama Research and Development (penelitian dan pengembangan). Penelitian dan pengembangan merupakan proses atau metode yang digunakan untuk memvalidasi dan mengembangkan produk. Yang dimaksud produk dalam hal ini tidak hanya sesuatu yang berupa benda seperti buku teks, film untuk pembelajaran dan software atau perangkat lunak untuk pembelajaran. Tetapi juga berupa metode seperti metode mengajar yang berupa program pengembangan.

Sedangkan menurut Richey \& Kelin (dalam Sugiyono, 2006:28) perancangan dan penelitian pengembangan adalah kajian yang sistematis tentang bagaimana membuat rancangan suatu produk, mengembangkan/memproduksi rancangan tersebut, dan mengevaluasi kinerja produk tersebut, dengan tujuan dapat diperoleh data yang empiris sebagai 
data yang dapat digunakan dalam pembelajaran atau nonpembelajaran.

Berdasarkan pendapat di atas, maka dapat disimpulkan bahwa penelitian pengembangan adalah suatu proses yang digunakan untuk mengembangkan dan memvalidasi produk-produk yang digunakan dalam pembelajaran maupun nonpembelajaran. Produk yang dihasilkan dalam bidang pembelajaran antara lain: buku teks, film untuk pembelajaran, software atau perangkat lunak untuk pembelajaran, metode seperti metode mengajar dan berupa program pengembangan.

\section{Keterampilan Menulis}

Sebagai suatu proses, menulis memerlukan latihan secara terus-menerus sehingga bisa terampil menulis. Oleh sebab itu, menulis juga dikategorikan sebagai salah satu keterampilan berbahasa. Seperti yang diungkapkan Tarigan (2013:3) bahwa menulis merupakan suatu keterampilan berbahasa yang dipergunakan untuk berkomunikasi secara tidak langsung, tidak secara tatap muka dengan orang lain. Selain itu, menulis merupakan suatu kegiatan yang produktif dan ekspresif.

Menulis merupakan salah satu dari empat keterampilan berbahasa yang mendasar (berbicara, mendengar, menulis dan membaca). Dewasa ini, keterampilan berpikir kritis (critical thingking) dan literasi (literacy skill) sudah menjadi keterampilan berbahasa lanjutan (Zainurrahman, 2013:2)

Berdasarkan beberapa pengertian di atas dapat disimpulkan bahwa menulis merupakan suatu proses karena melewati beberapa tahap. Menulis juga merupakan suatu keterampilan karena harus diasah dengan cara melakukan latihan secara terus menerus sehingga dalam menulis mengetahui sekedar teori tidaklah cukup. Semakin terampil dan terlatih seseorang dalam menulis, ia akan semakin terlatih mengatasi kecemasan dalam menulis.
Telah banyak ahli yang membuat klasifikasi tulisan. Sebagai contoh Weayer (dalam Tarigan, 2013:4) membuat klasifikasi sebagai berikut: (a) eksposisi: definisi, analisis; (b) deskripsi: deskripsi ekspositori, deskripsi literer; (c) narasi: urutan waktu, motif, konflik, titik pandang, pusat minat; (d) argumentasi: induksi, deduksi.

KI 4 kelas XI berisi tentang mengolah, menalar, dan menyaji dalam ranah konkret dan ranah abstrak terkait dengan pengembangan dari yang dipelajarinya di sekolah secara mandiri, bertindak secara efektif dan kreatif, serta mampu menggunakan metode sesuai kaidah keilmuan. Sedangkan Kompetensi Dasar (KD) tentang menyusun teks ceramah terdapat pada KD 4.6, yaitu: Mengonstruksi ceramah tentang permasalahan aktual dengan memerhatikan aspek kebahasaan dan menggunakan struktur yang tepat.

\section{Teks Ceramah}

Ceramah tidak jauh berbeda dengan pidato. Bentuk pembicaraan disampaikan di muka umum atau di hadapan banyak orang. Hanya ada sedikit perbedaan, kalau pidato jarang diakhiri dengan tanya jawab, tetapi ceramah biasanya pendengar diberikan waktu khusus untuk bertanya jawab (Syamsudin, 2005:49).

Untuk mempermudah siswa menulis teks ceramah siswa bisa menggunakan urutan-urutan tertentu. Seperti yang diungkapkan Surono (1987:91) bahwa dalam menyampaikan uraian ada urutan tertentu yang dapat digunakan, yaitu: urutan berdasarkan waktu terjadinya peristiwa, tempat terjadinya peristiwa, klasifikasi, sebab-akibat dan berdasarkan penyelesaian masalah.

Oleh karena itu, dapat disimpulkan bahwa teks ceramah adalah proses pengungkapan pikiran dalam bentuk katakata yang ditujukan kepada orang banyak berisi tentang suatu hal, pengetahuan dan sebagainya yang terdiri atas tiga bagian, 
yaitu pembukaan isi dan penutup. Dalam menulis teks ceramah seseorang harus memperhatikan pemilihan gagasan dan penggunaan bahasa.

Ceramah biasanya mempunyai ciri: (a) merupakan keterampilan berbahasa satu arah; (b) biasanya dilakukan dalam keperluan belajar mengajar klasikal; (c) pembicara berdiri di depan orang banyak untuk menyampaikan materi, sementara pendengar hanya menyimak saja; (d) merupakan kegiatan pasif reseptif.

Adapun secara umum tujuan utama seseorang harus berceramah adalah sebagai berikut: (a) untuk menginformasikan (to inform); (b) untuk menghibur (to entertain); (c) untuk membujuk, merayu dan mempengaruhi (to persuade).

Berdasarkan tujuan umum ceramah di atas, ceramah dibagi lagi ke dalam beberapa jenis ceramah, yaitu: (a) ceramah informatif; (b) ceramah argumentatif; (c) ceramah instruktif; (d) Ceramah persuasif e) ceramah rekreatif.

\section{Model Pembelajaran Problem Based Learning (PBL)}

Problem Based Learning (PBL) sebagai pembelajaran yang diperoleh melalui proses menuju pemahaman akan resolusi suatu masalah. Dalam hal ini sejalan dengan pendapat Dewey (dalam Trianto, 2007:91), bahwa pengajaran berdasarkan masalah merupakan pendekatan yang efektif untuk pengajaran proses berpikir tingkat tinggi. Pembelajaran ini sesuai untuk mengembangkan pengetahuan dasar maupun kompleks.

Model pembelajaran ini menekankan pada kemampuan penalaran yang memerlukan pemikiran kreatif. Pembelajaran pemecahan masalah adalah model pembelajaran yang menekankan pada kemampuan memecahkan masalah yang ditunjang dengan kemampuan penalaran, yakni kemampuan melihat hubungan sebab-akibat.
Berdasarkan beberapa pengertian di atas dapat disimpulkan bahwa model pembelajaran berbasis masalah merupakan sebuah model pembelajaran yang menitikberatkan pada pemahaman sehingga merangsang peserta didik untuk belajar kreatif dan kritis. Dalam kelas yang menerapkan pembelajaran berbasis masalah, peserta didik bekerja untuk memecahkan masalah.

Ciri-ciri pembelajaran berbasis masalah pembelajaran berbasis masalah memiliki ciri-ciri sebagai berikut: (a) pengajuan masalah atau pertanyaan; (b) keterkaitan dengan berbagai masalah disiplin ilmu; (c) penyelidikan yang autentik; (d) menghasilkan dan memamerkan hasil/karya gambar; dan (e) kolaborasi

Nasution (2011:170) menyatakan bahwa langkah-langkah proses pembelajaran berbasis masalah, yaitu: (a) peserta didik dihadapkan dengan masalah; (b) peserta didik merumuskan masalah itu; (c) peserta didik merumuskan hipotesis; dan (d) peserta didik menguji hipotesis itu.

Dengan PBL akan terjadi pembelajaran bermakna. Peserta didik yang belajar memecahkan suatu masalah maka mereka akan menerapkan pengetahuan yang dimilikinya atau berusaha mengetahui pengetahuan yang diperlukan. Belajar dapat semakin bermakna dan dapat diperluas ketika peserta didik berhadapan dengan situasi di mana konsep diterapkan

Sedangkan kekurangan dari metode ini adalah terkadang membutuhkan waktu yang lama dalam proses pembelajaran. Tetapi hal tersebut dapat diatasi dengan mempersempit masalah yang akan dibahas. Selain itu terbatasnya pengetahuan/wawasan siswa untuk memecahkan masalah dalam pembelajaran, merupakan hambatan besar dalam pelaksanaan model pembelajaran ini sehingga guru sebagai fasilitator harus banyak memberikan ilustrasi/contoh pemecahan masalah, yang kemudian dapat 
dijadikan acuan bagi siswa untuk memecahkan masalah yang dihadapinya.

\section{Media Gambar}

Gambar merupakan salah satu media pengajaran yang amat dikenal dalam setiap kegiatan pengajaran. Hal itu disebabkan kesederhanaannya, tanpa memerlukan perlengkapan, dan tidak perlu diproyeksikan untuk mengamatinya (Daryanto, 2016:126).

Teknik menulis dari gambar merupakan salah satu teknik kreatif dalam pembelajaran bahasa. Secara lebih lengkap Andayani (2015:30) mengungkapkan bahwa teknik pembelajaran menulis dari gambar bertujuan agar siswa dapat menulis dengan cepat berdasarkan gambar yang dilihat.

Dari pengertian media gambar di atas kita dapat mengambil kesimpulan bahwa memang benar media gambar merupakan media yang paling mudah dipahami dan tidak memerlukan peralatan khusus dalam penggunaannya.

Kelebihan media gambar adalah sifatnya konkret. Gambar/foto lebih realistis, dapat mengatasi masalah batasan ruang dan waktu, media gambar dapat mengatasi keterbatasan pengamatan, dapat memperjelas suatu masalah, dalam bidang apa saja dan untuk tingkat usia beberapa saja sehingga dapat mencegah atau membetulkan kesalahpahaman dan murah harganya, mudah didapat, mudah digunakan, tanpa memerlukan peralatan yang khusus.

Kekurangan media gambar antara lain penghayatan tentang materi kurang sempurna karena media gambar hanya menampilkan persepsi indra mata yang tidak cukup kuat untuk menggerakkan seluruh kepribadian manusia sehingga materi yang akan dibahas kurang sempurna; gambar atau foto benda yang terlalu kompleks kurang efektif untuk kegiatan pembelajaran dan ukuran sangat terbatas untuk kelompok besar.
Gambar dapat dipergunakan, baik dalam lingkungan anak-anak maupun dalam lingkungan orang dewasa. Gambar yang berwarna umumnya menarik perhatian. Semua gambar mempunyai arti, uraian dan tafsiran sendiri. Oleh karena itu, gambar dapat dipergunakan sebagai media pendidikan dan mempunyai nilainilai pendidikan bagi peserta didik yang memungkinkan belajar secara efisien peserta didik yang berkaitan dengan pemanfaatan media gambar dalam PBM.

\section{Rancangan Model}

Langkah-langkah pengembangan PBL dipadukan dengan media gambar, yaitu: (a) orientasi siswa pada masalah dengan bantuan media gambar; (b) mengorganisasikan siswa untuk belajar; (c) membimbing penyelidikan individu maupun kelompok; (d) mengembangkan dan menyajikan hasil karya dengan bantuan gambar; dan (e) menganalisis dan mengevaluasi proses pemecahan masalah.

\section{METODE PENELITIAN}

\section{Jenis Pengembangan}

Dalam penelitian ini Research and Development dimanfaatkan untuk mengembangkan model pembelajaran PBL pada materi menulis teks ceramah sebagai upaya meningkatkan prestasi belajar siswa. Model dalam penelitian pengembangan ini dibagi menjadi dua.

\section{a. Model Produk}

Model produk dalam penelitian pengembangan ini berupa model pembelajaran Problem Based Learning (PBL) yang dipadukan dengan media gambar pada materi menulis teks ceramah yang dikembangkan dengan model penelitian dan pengembangan (research and development).

\section{b. Model Proses}

Sedangkan model proses dalam penelitian pengembangan ini berupa model prosedural. Menurut Rohman dan Amri (2013:210) model pengembangan 
ADDIE dapat digunakan untuk berbagai macam bentuk pengembangan produk seperti model, strategi pembelajaran, metode pembelajaran, media dan bahan ajar. Model ADDIE terdiri atas lima siklus, yaitu siklus Analysis, Design, Development, Implementation, dan Evaluation.

\section{Prosedur Pengembangan \\ a. Tahap Analysis (A)}

Penelitian dan pengumpulan informasi, yang meliputi kajian pustaka, pengamatan atau observasi kelas dan persiapan laporan awal. Penelitian awal atau analisis kebutuhan sangat penting dilakukan guna memperoleh informasi awal untuk melakukan pengembangan. Hal ini dilakukan, melalui pengamatan kelas untuk melihat kondisi riil di lapangan. Pada tahap analisis ini dilakukan studi lapangan dan analisis kebutuhan.

\section{b. Tahap Design(D)}

Perencanaan mencakup merumuskan Standar Kompetensi dan Kompetensi Dasar. Hal yang penting dalam tahap ini adalah merancang bahan yang akan dijadikan subjek penelitian. Pengumpulan bahan dimaksudkan untuk memberikan informasi yang tepat untuk mengembangkan program-program atau produk sehingga program atau produk yang diujicobakan sesuai dengan tujuan yang ingin dicapai.

\section{c. Tahap Development (D)}

Pengembangan produk mencakup pengembangan perencanaan, materi dan evaluasi, yang kemudian dimuat dalam bahan ajar dan pegangan guru. Produk ini kemudian divalidasi oleh ahli materi, media dan praktisi. Setelah produk direvisi menghasilkan desain 2 kemudian tahap selanjutnya dilakukan uji coba produk.

\section{d. Tahap Implementation (I)}

Setelah dilakukan observasi terhadap kevalidan melalui validasi ahli materi, validasi ahli media dan praktisi.
Pertemuan pada tiap uji coba akan dilaksanakan masing-masing 1 kali, jadi jumlah pertemuan keseluruhan adalah 3 kali pertemuan.

Pada tahap ini dilakukan observasi terhadap kepraktisan produk melalui keterlaksanaan RPP dan angket respons siswa. Selain itu, melakukan observasi terhadap keefektifan produk melalui uji coba siswa dan aktivitas siswa pada proses pembelajaran penulisan teks ceramah dengan menggunakan model Problem Based Learning (PBL) dengan menggunakan media gambar.

Memberikan perlakuan berbeda antara uji coba perorangan yang melibatkan tiga siswa dan menghasilkan desain 3. Kemudian dilakukan uji coba kelompok kecil yang menghasilkan desain 4. Pada uji coba lapangan, guru menerapkan metode pembelajaran hasil revisi dari uji coba kelompok kecil. Sedangkan metode yang diterapkan pada uji coba kelompok kecil berasal dari perbaikan uji coba perorangan.

\section{e. Tahap Evaluation (E)}

Pada tahap ini dilaksanakan uji coba lapangan, uji coba tahap ini merupakan kegiatan uji coba lapangan operasional. Uji lapangan operasional pada 31 siswa kelas XI 2 SMA Negeri 8 PPU. Media yang sudah direvisi pada tahap ini dinamakan desain $\mathbf{5}$ atau yang disebut desain final yang siap diimplementasikan.

\section{HASIL DAN PEMBAHASAN}

Proses pengembangan bahan ajar dilaksanakan sejak 18 Januari 2017 di SMA Negeri 8 PPU. Tujuan kegiatan ini adalah tahap analisis, tahap desain, tahap pengembangan, tahap implementasi dan tahap evaluasi. Adapun proses pengembangan bahan ajar melalui beberapa tahap sebagai berikut.

\section{Tahap Analisis}

Tahap analisis dilakukan pada 18 hingga 31 Januari 2017. Kegiatan pada tahap ini, yaitu menganalisis studi 
kebutuhan dan analisis kebutuhan. Adapun hasil kegiatan yang diperoleh pada tahap ini sebagai berikut.

\section{a. Hasil Identifikasi Studi Lapangan}

SMA Negeri 8 PPU merupakan sekolah yang sudah menerapkan kurikulum 2013 yang sudah direvisi, yaitu berdasarkan Permendikbud nomor 24 tahun 2016 yang berisi tentang revisi silabus pembelajaran. Langkah-langkah pembelajaran yang digunakan di sekolah ini terdiri atas: (1) permodelan teks (2) konstruksi bersama, dan (3) konstruksi mandiri. Proses pembelajaran berjalan lancar walaupun terdapat beberapa hambatan. Hal itu terungkap dalam data yang diambil tanggal 18 Januari 2017 sebagai berikut.

\section{b. Hasil Identifikasi Analisis Kebutuhan}

Angket kebutuhan siswa diberikan pada siswa pada tanggal 6 Februari 2017 dengan subjek penelitian sebanyak 31 orang, yaitu pada siswa kelas XI 2 SMA Negeri 8 PPU. Dari aspek kebutuhan psikologis dapat simpulkan bahwa dari data kebutuhan rasa aman dapat simpulkan bahwa siswa merasa sangat aman belajar di sekolah, tidak merasa khawatir terhadap hasil belajar.

Selanjutnya, dari data kebutuhan kasih sayang dapat disimpulkan bahwa siswa merasa cukup mendapat kasih sayang karena siswa saling menghargai ketika melakukan sesuatu yang baik, sedangkan dari hasil angket kebutuhan penghargaan dapat disimpulkan bahwa siswa merasa senang terlibat dalam proses pembelajaran maupun dalam diskusi kelas, tetapi masih belum cukup mendapatkan kesempatan untuk mengemukakan pendapat. Siswa cenderung lebih senang dengan materi berbentuk puisi dan drama. Sedangkan dari data kebutuhan sosialisasi diri dapat disimpulkan bahwa pelajaran di sekolah memberi kesempatan untuk kreatif tetapi motivasi belajar siswa pada umumnya masih terbilang cukup rendah.

\section{Tahap Desain}

Tahap studi pengembangan desain dilaksanakan pada tanggal 7 Februari 2017. Tujuan tahap studi pengembangan ini adalah mengembangkan desain berdasarkan kegiatan sebelumnya. Proses hasil kegiatan pada tahap ini sebagai berikut.

a. Penentuan Kompetensi Inti dan

\section{Kompetensi Dasar}

KI yang digunakan dalam penelitian ini adalah KI 4, yang berkaitan dengan keterampilan atau praktik. Sedangkan KD yang digunakan KD 4.6, yaitu: mengonstruksi ceramah tentang permasalahan aktual dengan memerhatikan aspek kebahasaan dan menggunakan struktur yang tepat.

\section{b. Pengumpulan Bahan}

Pengumpulan data dilakukan dengan memperhatikan beberapa hal, yaitu: Jenis data, teknik pengumpulan data, dan teknik analisis data, pemetaan, penentuan populasi, dan tempat penelitian. Berikut pembahasan tentang pengumpulan bahan penelitian.

Penelitian ini melibatkan tiga orang validator, tiga orang siswa pada uji coba perorangan, sepuluh orang siswa pada uji coba kelompok kecil, dan tiga puluh satu orang siswa pada uji coba lapangan sebagai subjek penelitian atau sampel. Uji dilaksanakan di SMA Negeri 8 PPU, yang beralamat di Jalan Coastal Road, Km.1,5 Kel. Nipah-Nipah, Kec. Penajam, Kab. Penajam paser Utara, Provinsi Kalimantan Timur.

\section{c. Model PBL yang Telah Ada: Penyusunan Perencanaan, Materi Ajar dan Evaluasi}

Ada beberapa acuan yang dijadikan penulisan bahan ajar, yaitu perencanaan, 
materi ajar dan evaluasi. Pada tahap ini penyusunan perencanaan, materi ajar dan evaluasi belum menggunakan media gambar.

\section{Tahap Pengembangan}

\section{a. Pengembangan PBL dengan Media Gambar}

Pada tahap ini penyusunan perencanaan, materi ajar dan evaluasi dengan PBL dengan menggunakan media gambar. Kegiatan menulis dan menyusun bahan ajar tersebut dilakukan pada 18 Januari 2017. Mendesain sampul luar dan dalam, kata pengantar, panduan, dan daftar isi, serta menyusunnya hingga bagian akhir dilakukan pada 31 Januari 2017.

\section{b. Validasi Produk (Desain 2)}

Proses validasi desain 2 dilaksanakan pada tanggal 16 Mei 2017. Proses ini divalidasi oleh dua validator yang terdiri atas: validator materi, validator media dan praktisi.

\section{c. Validasi Ahli Materi}

Proses validasi materi dimulai sejak 6 Februari 2017. Validator materi dan praktisi penelitian ini adalah Nurliani Maulida, M.Pd. dapat disimpulkan bahwa berdasarkan kelayakan RPP, kelayakan materi, kelayakan evaluasi dari ahli materi model pembelajaran Problem Based Learning (PBL) dipadukan media gambar dalam menulis teks ceramah ini memperoleh skor $70 \%$ dan dinyatakan layak untuk digunakan dalam proses pembelajaran.

\section{d. Validasi Media}

Proses validasi sajian dilaksanakan pada 18 Mei 2017. Validator media dalam penelitian ini adalah Hundari. Disimpulkan bahwa berdasarkan kelayakan RPP, kelayakan materi, kelayakan evaluasi dari praktisi model pembelajaran Problem Based Learning (PBL) dipadukan media gambar dalam menulis teks ceramah ini memperoleh skor $71 \%$ dan dinyatakan layak untuk digunakan dalam proses pembelajaran.

\section{e. Validasi Praktisi}

Kegiatan uji coba desain akhir buku siswa dilaksanakan di SMA Negeri 8 PPU mulai tanggal 7-13 September 2017. Dari hasil validasi dapat disimpulkan bahwa berdasarkan kelayakan RPP, kelayakan materi, kelayakan evaluasi dari ahli media model pembelajaran Problem Based Learning (PBL) dipadukan media gambar dalam menulis teks ceramah ini memperoleh skor $73 \%$ dan dinyatakan layak untuk digunakan dalam proses pembelajaran.

\section{f. Rekapitulasi Hasil dari Ketiga Validator}

Berdasarkan data di atas hasil validasi rata-rata, yaitu $79 \%$. Hasil ini diinterpretasikan dengan skala $61-80 \%$ sehingga dikategorikan baik/layak. Hasil rekapitulasi dengan kategori tersebut, menunjukkan bahwa buku siswa yang berjudul "Menulis Teks Ceramah dengan Media Gambar" memiliki kualitas baik/layak. Adanya penilaian ini menjadikan buku tersebut baik/layak digunakan oleh siswa Kelas XI sebagai penunjang kegiatan pembelajaran.

\section{Tahap Implementasi}

Pada tahap implementasi ini, aspek yang diuji adalah aspek kepraktisan. Pada tahap ini dilaksanakan uji coba perorangan dan uji coba kelompok kecil. Berikut ini akan dibahas hasil uji coba perorangan dan uji coba kelompok kecil.

\section{a. Uji Coba Perorangan (Desain 3)}

Kepraktisan terhadap desain 3 diperoleh dari skor hasil analisis keterlaksanaan rencana pelaksanaan pembelajaran dan respons siswa. Sedangkan keefektifan pada desain ini diperoleh dari nilai hasil uji coba perorangan dan aktivitas siswa. Adapun 
hasil kepraktisan dan keefektifan terhadap desain ini sebagai berikut.

\section{b. Kepraktisan Produk}

\section{(1) Hasil Analisis Keterlaksanaan Rencana Pelaksanaan Pembe- lajaran}

Pengamatan keterlaksanaan rencana pelaksanaan pembelajaran terhadap desain 3 dilaksanakan pada hari Kamis, 12 Oktober 2017 pada pukul 10.30—12.00 Wita. Kegiatan uji coba model ini dilakukan satu kali tatap muka. Aspek yang terlaksana dari pengamat adalah 37 . Jumlah skor aspek tertinggi adalah 44 . Hasil Berdasarkan keterlaksanaan rencana pelaksanaan pembelajaran, diperoleh hasil, yaitu $84 \%$ dengan kategori terlaksana.

\section{(2) Hasil Analisis Respons Siswa}

Pengamatan keterlaksanaan rencana pelaksanaan pembelajaran terhadap desain 3 dilaksanakan pada hari Kamis, 12 Oktober 2017 pada pukul 10.30-12.00 Wita. Kegiatan uji coba model ini dilakukan satu kali tatap muka. Materi yang diujikan, yaitu menulis teks ceramah dengan media gambar. Berdasarkan hasil rekapitulasi angket uji coba perorangan di atas diperoleh simpulan bahwa respons siswa terhadap media gambar dalam pembelajaran ini adalah positif.

\section{c. Keefektifan}

Keefektifan terhadap desain akhir berupa skor hasil analisis yang diperoleh dari hasil tes siswa uji coba perorangan dan pengamatan terhadap aktivitas siswa. Adapun kegiatan yang dilakukan untuk mengetahui keefektifan terhadap desain ini sebagai berikut.

\section{(1) Hasil Uji Coba Perorangan}

Kegiatan pengamatan ini dilaksanakan pada hari Kamis, 12 Oktober 2017. Kegiatan ini dimulai dari pukul
07.20-08.50 Wita. Kegiatan uji coba desain ini dilakukan satu kali tatap muka.

Berdasarkan hasil uji coba perorangan, diperoleh data bahwa semua siswa mendapat nilai di atas KKM. Dari uji coba tersebut dapat diambil kesimpulan bahwa media gambar dapat membantu siswa dalam menulis teks ceramah.

(2) Hasil Pengamatan Aktivitas Siswa Jumlah rerata skor yang diperoleh dari validasi instrumen adalah 80\%. Berdasarkan kriteria penilaian di atas, maka hasil pengamatan aktivitas siswa termasuk pada kategori positif (baik).

\section{d. Revisi Berdasarkan Angket}

Revisi dalam uji coba desain 3 ini adalah materi terlalu ringkas dan pada bagian penutup karena penutup gambar masih terlalu umum, harus lebih rinci untuk memudahkan menyusun teks ceramah sesuai dengan tema. Selain itu siswa memberi komentar pada angket setidaknya satu gambar untuk satu paragraf, jadi tidak bingung lagi untuk mengembangkan teks ceramah.

\section{e. Rekapitulasi Hasil Validasi Desain 3}

Rekapitulasi hasil uji coba desain akhir bertujuan memudahkan memahami hasil uji coba desain ini secara menyeluruh. Rekapitulasi hasil uji coba ini, terdiri atas (1) uji kepraktisan berdasarkan hasil pengamatan terhadap keterlaksanaan RPP, dan (2) uji keefektifan berdasarkan data hasil respons siswa dan hasil uji coba kelompok kecil.

\section{f. Revisi terhadap Desain 3}

Berdasarkan hasil penelitian maka perlu perbaikan pada bagian isi karena materi terlalu ringkas gambar masih terlalu umum, harus lebih rinci untuk memudahkan menyusun teks ceramah sesuai dengan tema. Selain itu jumlah gambar yang disajikan kurang banyak. 


\section{g. Uji Coba Kelompok Kecil (Desain 4)}

Kepraktisan terhadap desain 4 diperoleh dari skor hasil analisis keterlaksanaan rencana pelaksanaan pembelajaran, respons siswa. Sedangkan keefektifan pada desain ini diperoleh dari nilai hasil uji coba perorangan dan aktivitas siswa. Adapun hasil kepraktisan dan keefektifan terhadap desain ini sebagai berikut.

\section{h. Kepraktisan Produk}

\section{(1) Hasil Analisis Keterlaksanaan RPP}

Pengamatan keterlaksanaan rencana pelaksanaan pembelajaran terhadap desain 4 dilaksanakan pada hari Rabu, 18 Oktober 2017 pada pukul 07.20—08.50 Wita. Kegiatan uji coba model ini dilakukan satu kali tatap muka. Materi yang diujikan, yaitu menulis teks ceramah dengan media gambar. Jumlah skor aspek yang terlaksana dari pengamat adalah 39 . Jumlah skor aspek tertinggi adalah 44 . Hasil Berdasarkan keterlaksanaan rencana pelaksanaan pembelajaran, diperoleh hasil, yaitu 89\% dengan kategori terlaksana.

\section{(2) Hasil Analisis Respons Siswa}

Pengamatan keterlaksanaan rencana pelaksanaan pembelajaran terhadap desain 4 dilaksanakan pada hari Rabu, 18 Oktober 2017 pada pukul 07.20-08.50 Wita. Kegiatan uji coba model ini dilakukan satu kali tatap muka. Materi yang diujikan, yaitu menulis teks ceramah dengan media gambar. Berdasarkan hasil rekapitulasi angket uji coba perorangan di atas diperoleh simpulan bahwa respons siswa terhadap media gambar dalam pembelajaran ini adalah positif.

\section{i. Keefektifan}

Keefektifan terhadap desain akhir berupa skor hasil analisis yang diperoleh dari hasil tes siswa uji coba perorangan dan pengamatan terhadap aktivitas siswa. Adapun kegiatan yang dilakukan untuk mengetahui keefektifan terhadap desain ini sebagai berikut.

\section{(1) Hasil Uji Coba Kelompok Kecil \\ Kegiatan pengamatan ini} dilaksanakan pada hari Rabu, 18 Oktober 2017. Kegiatan ini dimulai dari pukul 07.20-08.50 Wita. Kegiatan uji coba desain ini dilakukan satu kali tatap muka. Berdasarkan nilai yang diperoleh data bahwa semua siswa mendapat nilai di atas KKM. Dari data tersebut dapat diambil kesimpulan bahwa media gambar dapat membantu siswa dalam menulis teks ceramah.

\section{(2) Hasil Pengamatan Aktivitas Siswa} Jumlah rerata skor yang diperoleh dari validasi instrumen adalah 85\%. Berdasarkan kriteria penilaian di atas, maka hasil pengamatan aktivitas siswa masuk pada kategori Positif (baik).

\section{j. Revisi Berdasarkan Angket}

Hambatan dalam uji coba desain 3 ini adalah bahasa yang sulit untuk dipahami, gambar belum terlalu rinci dan belum ada keterangan pendahuluan isi dan penutup.

\section{k. Rekapitulasi Hasil Validasi Desain 4}

Rekapitulasi hasil uji coba desain akhir bertujuan memudahkan memahami hasil uji coba desain ini secara menyeluruh. Rekapitulasi hasil uji coba ini, terdiri atas (1) uji kepraktisan berdasarkan hasil pengamatan terhadap keterlaksanaan RPP, dan (2) uji keefektifan berdasarkan data hasil respons siswa dan hasil uji coba kelompok kecil.

\section{Revisi terhadap Desain 4}

Berdasarkan hasil penelitian maka perlu perbaikan pada bagian isi karena bahasa sulit dipahami, gambar masih terlalu umum, harus lebih rinci untuk memudahkan menyusun teks ceramah sesuai dengan tema. Selain itu jumlah belum ada pembagian yang jelas 
berdasarkan bagian teks ceramah, yaitu, pembukaan, isi dan penutup.

\section{Tahap Evaluasi (Desain 5)}

Kepraktisan terhadap desain 5 diperoleh dari skor hasil analisis keterlaksanaan rencana pelaksanaan pembelajaran, respons siswa. Sedangkan keefektifan pada desain ini diperoleh dari nilai hasil uji coba perorangan dan aktivitas siswa. Adapun hasil kepraktisan dan keefektifan terhadap desain ini sebagai berikut.

\section{Kepraktisan Produk}

\section{a. Hasil Analisis Keterlaksanaan RPP}

Pengamatan keterlaksanaan rencana pelaksanaan pembelajaran terhadap desain 4 dilaksanakan pada hari Rabu, 18 Oktober 2017 pada pukul 14.15-16.45 Wita. Kegiatan uji coba model ini dilakukan satu kali tatap muka. Materi yang diujikan, yaitu menulis teks ceramah dengan media gambar. Jumlah skor aspek yang terlaksana dari pengamat adalah 41 Jumlah skor aspek tertinggi adalah 44 . Hasil Berdasarkan keterlaksanaan rencana pelaksanaan pembelajaran, diperoleh hasil 93\% dengan kategori terlaksana.

\section{b. Hasil Analisis Respons Siswa}

Pengamatan keterlaksanaan rencana pelaksanaan pembelajaran terhadap desain 5 dilaksanakan pada hari Rabu, 18 Oktober 2017 pada pukul 14.15-16.45 Wita. Kegiatan uji coba model ini dilakukan satu kali tatap muka. Materi yang diujikan, yaitu menulis teks ceramah dengan media gambar. Berdasarkan hasil rekapitulasi angket uji coba lapangan di atas diperoleh simpulan bahwa respons siswa terhadap media gambar dalam pembelajaran ini adalah positif.

\section{Keefektifan}

Keefektifan terhadap desain akhir berupa skor hasil analisis yang diperoleh dari hasil tes siswa uji coba lapangan dan pengamatan terhadap aktivitas siswa. Adapun kegiatan yang dilakukan untuk mengetahui keefektifan terhadap desain ini sebagai berikut.

\section{a. Hasil Uji Coba Lapangan}

Berdasarkan hasil uji coba lapangan, diperoleh data bahwa semua siswa mendapat nilai di atas KKM. Dari uji coba ini, dapat diambil kesimpulan bahwa media gambar dapat membantu siswa dalam menulis teks ceramah.

\section{b. Hasil Pengamatan Aktivitas Siswa}

Jumlah rerata skor yang diperoleh dari validasi instrumen adalah 90\%. Berdasarkan kriteria penilaian di atas, maka hasil pengamatan aktivitas siswa termasuk pada kategori Positif (Sangat Baik).

\section{Revisi Berdasarkan Angket}

Revisi dalam uji coba desain 3 ini adalah bahasa yang sulit untuk dipahami, gambar belum terlalu rinci dan belum ada keterangan pendahuluan isi dan penutup.

\section{Rekapitulasi Hasil Validasi Desain 5}

Rekapitulasi hasil uji coba desain akhir bertujuan memudahkan memahami hasil uji coba desain ini secara menyeluruh. Rekapitulasi hasil uji coba ini, terdiri atas (1) uji kepraktisan berdasarkan hasil pengamatan terhadap keterlaksanaan RPP, dan (2) uji keefektifan berdasarkan data hasil respons siswa dan hasil uji coba kelompok kecil. Hasil uji coba desain ini adalah media layak digunakan dengan revisi.

\section{Revisi terhadap Desain $\mathbf{5}$}

Berdasarkan koreksi terhadap desain 5 kegiatan selanjutnya adalah melakukan revisi. Tujuan dari kegiatan ini memperbaiki desain 5, sebagai bahan ajar yang telah dikoreksi uji coba lapangan sehingga desain ini yang telah direvisi ini dapat menghasilkan desain akhir. 
Berdasarkan hasil penelitian maka disimpulkan perlu perbaikan.

Setelah dilakukan revisi berdasarkan uji kelayakan/kevalidan, uji kepraktisan dan keefektifan maka diperoleh data bahwa pengembangan pembelajaran menulis teks ceramah dengan model pembelajaran Problem Based Learning dipadukan media gambar pada siswa kelas XI SMA dinyatakan layak untuk digunakan dalam proses pembelajaran.

\section{E. PENUTUP}

Model perencanaan pembelajaran kemampuan menulis teks ceramah melalui model Problem Based Learning (PBL) siswa kelas XI SMA, berupa RPP yang terdiri atas lima langkah, yaitu: orientasi siswa pada masalah dengan bantuan media gambar; mengorganisasikan siswa untuk belajar; membimbing penyelidikan individu maupun kelompok; mengembangkan dan menyajikan hasil karya dengan bantuan gambar, serta; menganalisis dan mengevaluasi proses pemecahan masalah. Model materi ajar pembelajaran kemampuan menulis teks ceramah melalui model Problem Based Learning (PBL) siswa kelas XI SMA, berupa:, materi/bahan ajar penulisan teks ceramah. Model evaluasi pembelajaran kemampuan menulis teks ceramah melalui model Problem Based Learning (PBL) siswa kelas XI SMA adalah tes psikomotor beserta rubrik penilaiannya, yaitu penilaian psikomotor yang meliputi, kesesuaian isi dengan gambar, unsur kebahasaan, kosakata dan kalimat. Hasil pengembangan diperoleh berdasarkan tiga aspek, yaitu kevalidan, kepraktisan dan keefektifan.

\section{DAFTAR PUSTAKA}

Adeninawaty, D., Soe'oed, R., \& Ridhani, A. (2018). Penerapan Model Pembelajaran Discovery Learning Strategi Think Talk Write dalam Meningkatkan Motivasi dan Hasil Belajar Menulis Teks Ulasan Kelas
VIII SMP. Diglosia: Jurnal Kajian

Bahasa, Sastra, dan

Pengajarannya, 1(2), 75-88. Diperoleh dari

http://jurnal.fkip.unmul.ac.id/inde x.php/diglosia/article/view/10

Andayani. (2015). Problema dan Aksioma: Dalam Metodologi Pembelajaran Bahasa Indonesia. Yogyakarta: Deepublish.

Daryanto. (2016). Media Pembelajaran. Edisi Ke-2 Revisi. Yogyakarta: Gava Media.

Dewi, P., Hudiyono, Y., \& Mulawarman, W. G. (2018). Pengembangan Bahan Ajar Menulis Teks Prosedur Kompleks dengan Model Pembelajaran Discovery Learning Menggunakan Media Audio Visual (Video) di Kelas XI SMA Negeri 1 Samarinda. Diglosia: Jurnal Kajian Bahasa, Sastra, Dan Pengajarannya, 1(2), 101-112. Diperoleh dari http://jurnal.fkip.unmul.ac.id/inde x.php/diglosia/article/view/12

Jones, V. F., \& Jones, L. S. (1992). Comprehensive Classroom Management. America: The Unitated States of America

Kemdikbud. (2013). Bahasa Indonesia: Ekspresi Diri dan Akademik Kelas XI. Jakarta: Kemdikbud.

Lestari, I. (2012). Pengembangan Bahan Ajar Berbasis Kompetensi. Jakarta: Akademia.

Nasution \& Thomas, M. (2014). Buku Penuntun Membuat Tesis, Skripsi, Disertasi, Makalah. Jakarta: Bumi Aksara.

Nasution, S. (2011). Berbagai Pendekatan dalam Proses Belajar dan Mengajar. Jakarta: Bumi Aksara.

Rohman, M. \& Amri, S. (2013). Strategi dan Desain Pengembangan Sistem 
Pembelajaran. Jakarta: Prestasi Pustaka.

Septhin, K., Mulawarman, W. G., \& Suhatmady, B. (2018). Hubungan Minat Baca dengan Kemampuan Menulis Teks Ekposisi Siswa Kelas XI SMK Negeri 9 Samarinda. Diglosia: Jurnal Kajian Bahasa, Sastra, dan Pengajarannya, 1(2), 89-100. Diperoleh dari http://jurnal.fkip.unmul.ac.id/inde x.php/diglosia/article/view/11

Sugiyono. (2006). Metode Penelitian Pendidikan Pendekatan Kuantitatif, Kualitatif dan R\&DD. Bandung: Alfabeta.
Surono. (1987). Pemandu Pelajaran Bahasa dan Sastra Indonesia. Solo: Tiga Serangkai.

Sutikno, S. 2014. Metode dan Model-Model Pembelajaran. Menjadikan Proses Pembelajaran Lebih Variatif, Aktif, Inovatif, Efektif dan Menyenangkan. Lombok: Holistica.

Tarigan, H. G. (2013). Menulis sebagai Suatu Keterampilan Berbahasa. Bandung: Angkasa.

Trianto. (2007). Model-Model Pembelajaran Inovatif Berorientasi Konstruktivistik. Jakarta: Pustaka Prestasi.

Zainurrahman. (2013). Menulis dari Teori Hingga Praktik. Bandung: Alfabeta. 
